\title{
PENGEMBANGAN MEDIA PEMBELAJARAN BERDASARKAN HASIL-HASIL PENELITIAN BOGA SEBAGAI USAHA PENINGKATAN MUTU PANGAN
}

\author{
${ }^{1}$ Risa Panti Ariani, ${ }^{2} \mathrm{Ni}$ Made Suriani, ${ }^{3} \mathrm{Ni}$ Wayan Marti \\ 1,2Jurusan Pendidikan Kesejahteraan Keluarga, 3Jurusan Informatika, \\ Fakultas Teknik dan Kejuruan, Universitas Pendidikan Ganesha \\ Singaraja, Indonesia
}

email: rp_ariani@yahoo.co.id

\begin{abstract}
Abstrak
Tujuan penelitian ini untuk mengembangkan media pembelajaran pangan berdasarkan hasil-hasil penelitian boga sebagai usaha peningkatan mutu pangan. Permasalahan penelitian pada tahun kedua ini dirumuskan: (a) Bagaimanakah penggunaan media pembelajaran pangan berbasis hasil-hasil penelitian boga (CD Interaktif Pangan) pada mata kuliah Pengawetan Makanan? (b) Apakah pemanfaatan media pembelajaran pangan (CD Interaktif Pangan) dapat meningkatkan kemampuan mahasiswa untuk menemukan produk pangan baru yang kreatif dan inovatif? Responden adalah mahasiswa Program Studi Tata Boga Jurusan Pendidikan Kesejahteraan Keluarga yang mengambil mata kuliah Pengawetan Makanan Semester Ganjil tahun akademik 2012/2013 dalam 12 kali pertemuan. Penelitian ini memberikan perlakuan yang berbeda pada dua kelompok belajar yang menggunakan media belajar CD Interaktif dan tidak. Langkah kegiatan penelitian ini meliputi 8 kegiatan dengan pengambilan data menggunakan lembar observasi dan lembar kerja. Sedangkan eksperimen dilakukan untuk memperoleh produk pangan baru, kemudian uji organoleptik digunakan untuk menilai uji kualitas produk pangan. Hasil penelitian ini adalah (a) penggunaan media pembelajaran pangan berbasis hasil-hasil penelitian boga pada mata kuliah Pengawetan Makanan dapat meningkatkan pengetahuan, keterampilan dan aktivitas mahasiswa. Hal ini disebabkan mahasiswa dapat memahami materi dengan melihat media pembelajaran dalam bentuk CD interaktif pangan. (b) pemanfaatan CD Interaktif Pangan dapat meningkatkan kemampuan mahasiswa untuk menemukan produk pangan baru yang kreatif dan inovatif. Selain itu dampak ikutan dalam penelitian ini mahasiswa memiliki pengalaman dalam berpikir rasional (mulai menyusun rancangan sampai laporan) dan melakukan pengkomunikasian melalui presentasi. Produk pangan baru yang diperoleh terdiri dari 16 resep sebagai berikut Opak Wortel, Opak Ubi Ungu, Bakso Timbul, Ice Cream Tello, Dodol Labu Kuning, dodol Wortel, Bakso Ampas Tahu, Mie Wortel, Cookies Ubi, Cake Tamarillo, Abon Timbul, Opak Ampas tahu, Chiffon Ubi Ungu, Sukade, Mi Sukun dan Yoghurt Nabati.
\end{abstract}

Kata kunci: CD Interaktif, media pembelajaran, mutu pangan dan produk pangan 


\begin{abstract}
The purpose of this study was to develop a learning medium of food based on the results of boga research in an effort to improve the quality of food. Problems in the second year of this study was formulated: (a) How does the use of foodbased instructional media boga research results (Food Interactive CD) at Food Preservation courses? (b) Is the use of instructional media (Food Interactive CD) can improve student's ability to find new food products that are creative and innovative? Respondents were students of Program Studi Tata Boga Jurusan Pendidikan Kesejahteraan Keluarga who took a course Preserving Food Semester of the academic year 2012/2013 in 12 meetings. This study gives a different treatment in the two study groups using interactive media learning CDs and not using CDs. Steps of activities of research use 8 activities of data collection using observation sheets and worksheets. While the experiments conducted to obtain a new food product, then organoleptic test was used to assess the quality of food products. The results of this study were (a) the CDs media research boga can enhance the knowledge skills and student activities. This is due to the students understand the material by looking at instructional media in the form of an interactive CD. ( $b$ ) utilization of Interactive CD can enhance students' ability to find new food products that are creative and innovative. In addition to the impacts on students is that they get more experience in rational thinking (start from drafting up the report) and does better communicating through presentation. New food product obtained consisted of the following 16 new recipes which are Opak Wortel, Opak Ubi Ungu, Bakso Timbul, Ice Cream Tello, Dodol Labu Kuning, dodol Wortel, Bakso Ampas Tahu, Mie Wortel, Cookies Ubi, Cake Tamarillo, Abon Timbul, Opak Ampas tahu, Chiffon Ubi Ungu, Sukade, Mi Sukun and Yoghurt Nabati.
\end{abstract}

Keywords : Interactive CD, instructional media, the quality of food and food products

\section{PENDAHULUAN}

Pengawetan

makanan

merupakan mata kuliah yang berisikan materi teknologi pangan pada mahasiswa program studi Tata Boga Jurusan Pendidikan Kesejahteraan Keluarga (PKK). Pembelajaran teknologi pangan pada tahun-tahun sebelumnya masih dilakukan secara konvensional, dengan metode ceramah, tanya jawab dan praktik. Isi, organisasi, dan strategi pembelajaran dirasakan masih kurang optimal untuk mengakomodasi kemampuan kecakapan hidup yang dibutuhkan lulusannya di sekolah dan masyarakat. Dosen sebagai kolaborator dalam penelitian ini diharapkan dapat mengatasi berbagai alasan klasik mengenai keterbatasan waktu, fasilitas yang dimiliki lembaga. Kesadaran untuk menanamkan kecakapan hidup (life skills) secara maksimal pada jenjang perguruan tinggi menguat setelah menyikapi tuntutan hidup di masyarakat.

Mahasiswa Tata Boga selain diharapkan sebagai calon guru di sekolah-sekolah kejuruan, juga dituntut memiliki kemampuan yang berkualitas dalam wirausaha, karena terbatasnya kesempatan untuk menjadi guru ataupun menjadi pegawai pada institusi non pemerintah. Pembelajaran pada bidang Tata Boga memiliki ciri yang bersinergi dalam berbagai ranah ilmu seperti ilmu pangan, ilmu kesehatan, seni, sosial-ekonomi, rekayasa 
hidangan, usaha makanan (jasa boga) dan kuliner pada budaya-budaya tertentu, dengan mengutamakan keterampilan memasak yang bercitarasa terbaik. Ciri keilmuan Tata Boga semacam ini memerlukan media pembelajaran yang kreatifif dan Inovatif, sehingga dapat dikomunikasikan pada mahasiswa. Deskripsi pembelajaran teknologi pangan pada mata kuliah Pengawetan Makanan adalah mahasiswa mempunyai pengetahuan dan keterampilan dalam pengawetan makanan dengan menggunakan teknologi tepat guna, serta mampu menganalisis bahan pangan secara sederhana untuk memperoleh makanan bermutu. Berbagai strategi dalam proses pembelajaran tersebut dan penggunaan berbagai media pembelajaran telah banyak digunakan agar dapat mencapai tujuan pembelajaran secara maksimal.

Penelitian ini berawal dari pentingnya pengkomunikasian temuantemuan pangan bermutu yang dihasilkan melalui berbagai penelitian pangan yang berbentuk skripsi mahasiswa dan hasil penelitian Tata Boga. Hasil-hasil penelitian boga ini, seharusnya dikomunikakan pada masyarakat agar bermanfaat untuk memperoleh makanan bermutu yang memiliki nilai ekonomis sehingga dapat dijadikan produk jasa boga. Dengan meningkatnya kemampuan pengolahan makanan bermutu pada mahasiswa diharapkan juga mampu memotivasi untuk membuka peluang usaha jasa boga. Selain itu, hasil-hasil penelitian boga tersebut menggunakan berbagai bahan makanan yang ada dilingkungan, berharga murah dan memiliki kandungan gizi yang cukup. Keragaman hayati (biodiversity) yang tersebar di wilayah Indonesia merupakan potensi besar yang dapat diolah menjadi berbagai makanan. Hal ini sekaligus menjadi peluang yang dapat mengantar Indonesia untuk meningkatkan ketahanan pangan. Pelaksanaan diversifikasi konsumsi pangan secara bertahap akan mengubah pola produksi pertanian di tingkat petani (diversifikasi produksi pertanian). Petani akan memproduksi bahan makanan yang banyak dibutuhkan oleh konsumen karena memiliki nilai ekonomis. Kondisi ini akan membawa dampak pada peningkatan perekonomian petani. Mereka tidak lagi tergantung pada bahan makanan tertentu sebagai sumber pendapatan usaha taninya. Oleh karena itu upaya diversifikasi konsumsi pangan, dan menggantikannya dengan jenis pangan lain yang tersedia dilingkungan sekitar menjadi penting dilakukan dalam rangka menjaga ketahanan pangan.

Kebutuhan kecakapan hidup dalam zaman teknologi yang penuh persaingan menuntut mahasiswa kreatif melakukan inovasi-inovasi, tidak hanya reseptif (hanya melakukan sesuai petunjuk kerja dalam resep). Mahasiswa harus mampu melakukan inovasi-inovasi produk agar tetap mampu mempertahankan hidup. Pembelajaran kecakapan hidup melalui media pembelajaran pangan sebagai upaya peningkatan mutu pangan kiranya dapat mengakomodasi tuntutan ini. Pangan sebagai produk akan berorientasi pada pengetahuan dan hasil produk pangan tersebut, sementara pangan sebagai proses akan menekankan pada keterampilan berinovasi atau berimprovisasi cara-cara 
kreatif untuk menghasilkan produk baru yang lebih baik atau lebih unggul. Melalui pengembangan media pembelajaran berdasarkan hasil-hasil penelitian boga sebagai usaha peningkatan mutu pangan diharapkan mampu menumbuh kepercayaan diri mahasiswa bahwa mereka punya potensi untuk mengembangkan suatu produk pangan yang bermutu. Selain itu juga memiliki nilai ekonomis untuk peningkatan ketahanan pangan masyarakat setempat, maka permasalahan dirumuskan sebagai berikut:

(1) Bagaimanakah penggunaan media pembelajaran pangan berbasis hasilhasil penelitian boga (CD Interaktif Pangan) pada mata kuliah Pengawetan Makanan?

(2) Apakah pemanfaatan media pembelajaran pangan (CD Interaktif Pangan) dapat meningkatkan kemampuan mahasiswa untuk menemukan produk pangan baru yang kreatif dan inovatif?

Penelitian ini memiliki tujuan untuk mengembangkan media pembelajaran pangan berdasarkan hasil-hasil penelitian boga sebagai usaha peningkatan mutu pangan. Selain itu juga penelitian ini menemukan media pembelajaran pangan yang mengakomodasikan hasil-hasil penelitian di program studi Tata Boga. Pembelajaran yang kreatif dan inovatif dengan berbasis multimedia ini, diharapkan mampu meningkatkan pengetahuan dan keterampilan mahasiswa tentang produk pangan bermutu, sebagai upaya memotivasi untuk peningkatan diversifikasi pangan.

\section{METODE}

Penelitian tahun pertama (tahun 2011) terbatas pada tahapan penelitian yang membuat media pembelajaran dengan isi teknologi pangan yang masih terbatas. Maksudnya penelitian tahun pertama memanfaatkan hasil-hasil penelitian boga dari tahun 2007 sampai 2011 (32 produk pangan) sebagai media pembelajaran pangan yang kreatif dan inovatif. Penelitian tahun kedua dengan fokus kegiatan pemanfaatan media pembelajaran pangan (CD Interaktif Pangan). Pemahaman kecakapan hidup tentang mutu pangan yang kreatif dan inovatif dapat dioptimalkan dengan melibatkan mahasiswa dalam praktik kerja ilmiah. Pelibatan mahasiswa dalam kegiatan tersebut akan membawa efek ikutan berupa peningkatan pengetahuan dan keterampilan tentang kualitas pangan melalui langkah kerja ilmiah.

Penelitian ini memiliki tujuan jangka panjang untuk mengembangkan media pembelajaran pangan berdasarkan hasil-hasil penelitian boga sebagai usaha peningkatan mutu pangan. Tujuan tahun kedua penelitian ini adalah menemukan produk pangan bermutu yang kreatif dan inovatif sebagai usaha peningkatan mutu pangan berdasarkan hasil-hasil penelitian boga. Selain itu juga penelitian ini dapat menghasilkan suatu media pembelajaran pangan baru sesuai dengan perkembangan kognitif dan pengalaman belajar mahasiswa melalui (1) Penggunaan CD Interaktif Pangan sebagai media pembelajaran pangan yang kreatif dan inovatif pada mata kuliah Pengawetan Makanan. (2) Memperoleh manfaat media pembelajaran pangan (CD Interaktif 
Pangan) untuk meningkatkan kemampuan mahasiswa menemukan produk pangan bermutu yang kreatif dan inovatif.

Pada tahun kedua ini pemanfaatan CD Interaktif pangan dan buku ajar "Pengawetan Makanan" dalam proses pembelajaran mata kuliah Pengawetan Makanan agar mahasiswa mampu menemukan produk pangan baru yang kreatif dan inovatif, serta meningkatkan motivasi mahasiswa sebagai usaha peningkatan mutu pangan. Langkah kerja ilmiah peningkatan mutu pangan ini meliputi 8 kegiatan pada mata kuliah Pengawetan Makanan yang dilaksanakan dalam 12 kali pertemuan, sbb: (1) pengungkapan pengetahuan awal tentang upaya peningkatan mutu pangan dan keterampilan kerja ilmiah awal; (2) pembekalan peningkatan mutu pangan; (3) memiliki pengalaman langsung tentang peningkatan mutu pangan; (4) menemukan ide inovatif produk pangan bermutu; (5) membuat rancangan produk pangan baru; (6) pelaksanaan praktik oleh mahasiswa; (7) pembuatan media tentang produk pangan baru; (8) pengkomunikasian produk pangan baru melalui presentasi hasil di kelas.

Responden adalah mahasiswa Program Studi Tata Boga Jurusan Pendidikan Kesejahteraan Keluarga yang mengambil mata kuliah Pengawetan Makanan pada Semester Ganjil tahun akademik 2012/2013. Eksperimen dilakukan untuk menemukan produk pangan bermutu, sedangkan organoleptik digunakan untuk menilai uji kualitas produk pangan baru.

Penelitian ini dilakukan di
laboratorium produksi Tata Boga

Jurusan Pendidikan Kesejahteraan

Keluarga, Fakultas Teknik dan

Kejuruan, Universitas Pendidikan

Ganesha Singaraja. Pelaksanaan penelitian ini dilakukan selama 10 (sepuluh) bulan pada dimulai pada bulan Februari sampai dengan Nopember 2012.

Waktu tatap muka menggunakan jam perkuliahan Pengawetan Makanan pada semester Ganjil tahun 2012/2013 dengan pertemuan sebanyak satu kali dalam seminggu. Jumlah pertemuan pada penelitian ini adalah 12 kali pertemuan. Penelitian pengembangan ini ditekankan pada langkah awal untuk memanfaatkan media pembelajaran pangan dalam bentuk CD Interaktif Pangan dan buku ajar yang merupakan luaran penelitian Hibah Bersaing ini pada tahun pertama. CD Interaktif Pangan berbasis hasil-hasil penelitian mahasiswa dan dosen tentang boga/pangan, digunakan sebagai media pembelajaran pada mahasiswa yang mengambil mata kuliah Pengawetan Makanan di program studi Tata Boga. Jumlah mahasiswa yang mengambil mata kuliah ini sebanyak 36 orang yang dibagi menjadi dua kelas, setiap kelas terdiri dari 18 mahasiswa, tetapi 2 orang mahasiswa mengundurkan diri pada kelompok II. Pada kelompok pertama mahasiswa memperoleh CD Interaktif Pangan dan buku ajar, sedangkan pada kelompok kedua hanya memperoleh buku ajar saja. Meskipun demikian perlakuan yang diberikan pada setiap kelas sama, dengan langkah-langkah kegiatan. Tetapi karena siswa memerlukan pengarahan dan bimbingan secara intensif, maka pertemuan dengan siswa atau kelompok dapat 
dilakukan sewaktu-waktu diluar jam pelajaran sesuai kondisi.

Keutamaan penelitian ini memanfaatkan hasil-hasil penelitian boga sebagai media pembelajaran pangan yang kreatif dan inovatif dengan prosedur kegiatan penelitian dalam 12 kali pertemuan sebagai berikut:

1) Pertemuan I : Pre test tentang pengungkapan pengetahuan awal dalam upaya peningkatan mutu pangan dan keterampilan kerja ilmiah awal; dengan menjawab pertanyaan pada buku ajar Pengawetan Makanan

2) Pertemuan II : pemberian materi tentang peningkatan mutu pangan, dengan cara ceramah dan tanya jawab. Kelompok pertama materi dilengkapi dengan CD Interaktif pangan, sedangkan kelompok kedua tidak menggunakan CD Interaktif pangan.

3) Pertemuan III : Persiapan dan perencanaan praktik produk pangan sesuai CD Interaktif Pangan yang hanya diberikan pada kelompok I. Bimbingan diberikan oleh dosen pengampu mata kuliah.

4) Pertemuan IV : praktik sesuai produk hasil penelitian HB tahun pertama, sehingga mahasiswa memiliki pengalaman langsung (praktikLembar Observasi 1) tentang peningkatan mutu pangan di Laboratorium Produksi Boga. Praktik kelompok dengan waktu berbeda karena keterbatasan laboratorium.

5) Pertemuan V : menemukan ide inovatif produk pangan bermutu melalui diskusi kelompok kecil dengan panduan berdasarkan Lembar Kerja yang dilanjutkan pada rancangan produk pangan. (pertemuan ke 6)

6) Pertemuan $\mathrm{VI}:$ membuat rancangan produk pangan baru melalui diskusi kelompok kecil dan bimbingan oleh dosen pengampu mata kuliah.

7) Pertemuan VII : pelaksanaan praktik oleh mahasiswa untuk memperoleh formulasi produk pangan baru yang inovatif dan kreatif; di Laboratorium Produksi Boga. Praktik kelompok berbeda waktu.

8) Pertemuan VIII : pelaksanaan praktik perbaikan oleh mahasiswa untuk memperoleh formulasi yang tepat; di Laboratorium Produksi Boga. (pertemuan ini dilakukan beberapa kali sampai menemukan produk pangan yang bermutu sesuai kriteria dalam uji organoleptik)

9) Pertemuan IX : penyusunan media tentang tentang produk pangan baru yang inovatif dan kreatif, melalui konsultasi kualitas produk pangan baru.

10) Pertemuan $X$ dan $X I$ : pengkomunikasian produk pangan baru melalui presentasi hasil di depan kelas.

11) Pertemuan XII : Evaluasi Kegiatan, secara lebih dalam difokuskan pada masalah-masalah yang ada dalam pelaksanaan kegiatan untuk memperoleh produk pangan baru melalui uji kualitas, serta menemukan alternatif pemecahan masalah yang direkomendasikan sebagai usaha peningkatan mutu pangan.

Pengumpulan data dilakukan melalui Lembar Kerja (Perencanaan Praktik) dan Lembar Observasi pada setiap kegiatan eksperimen/uji coba melalui praktik pengolahan produk 
pangan hasil penelitian yang dilaksanakan sesuai program pembelajaran pada mata kuliah Pengawetan Makanan. Lembar Kerja terdiri dari 1) perencanaan alat dan bahan,serta prosedur kerja; 2) pelaksanaan eksperimen; 3) produk yang diperoleh (sudah dikemas) diuji secara organoleptik dan dianalisis; 4) dokumentasi kegiatan dan pembuatan laporan eksperimen; 5) pengkomunikasian hasil eksperimen melalui diskusi dan presentasi produk hasil. Sedangkan lembar observasi digunakan untuk mengamati pelaksanaan prosedur eksperimen dan produk hasil uji coba. Penelitian yang dilakukan ditahun kedua ini dirancang dalam bentuk CD interaktif dengan produk pangan baru yang kreatif dan inovatif. Media pembelajaran ini dapat digunakan sebagai bahan ajar mata kuliah Pengawetan Makanan.

Dalam penelitian ini, dikaji pengembangan media pembelajaran pangan yang berbentuk CD Interaktif yang meliputi materi Prakata (Home), Bahan pangan berisi hasil-hasil uji coba/eksperimen berdasarkan bahan pangan utama yang diteliti mulai dari identitas dan produk hasil, tahapan persiapan alat, persiapan bahan, proses pengolahan produk, dan catatan mutu produk pangan yang merupakan hasil uji kualitas serta sesuai kekhasan produk pangan tersebut. Sesuai dengan masalah yang hendak dipecahkan dan sifat informasi yang dikumpulkan, maka analisis data dilakukan dengan menginterpretasi informasi yang ada atau dikenal dengan cara analisis interpretative. Cara analisis tersebut digunakan untuk membangun makna dari fakta-fakta yang ada sehingga keberadaan objek dapat dipahami dengan baik. Hasil interpretasi informasi disajikan secara deskriptif sesuai dengan masalah-masalah yang menjadi fokus penelitian. Hasil penelitian ini disajikan dalam bentuk deskripsi yang menggambarkan keadaan objek yang meliputi pemaparan fakta dan makna yang dibangun secara terintegrasi.

\section{HASIL DAN PEMBAHASAN \\ Penggunaan media CD Interaktif Pangan}

Hasil penelitian yang diperoleh merupakan data berdasarkan Lembar observasi penelitian pangan ini untuk mengetahui penggunaan media pembelajaran pangan berbasis hasilhasil penelitian boga (CD Interaktif Pangan) pada mata kuliah Pengawetan Makanan, yaitu:

1) Perkembangan pengetahuan pada kelompok pertama (nilai rata-rata 80,61 menjadi 86,39) lebih tinggi dari kelompok kedua (nilai rata-rata 80.88 menjadi 83.11) berdasarkan nilai rata-rata hasil pretes dan postes.

2) Perkembangan keterampilan dasar mahasiswa dalam eksperimen pada kelompok pertama pengulangan praktik terjadi sampai rata-rata 1,6 kali, sedangkan pada kelompok kedua pengulangan praktik terjadi sampai rata-rata 2,7 kali.

3) Perkembangan aktivitas pada kelompok pertama lebih tinggi dari pada kelompok kedua berdasarkan banyaknya pertanyaan, kualitas pertanyaan dan kemampuan menjawab serta menguraikan setiap masalah produk pangan.

Kelompok pertama mempelajari

CD interaktif pangan hasil penelitian 
tahun pertama, kemudian melakukan uji coba produk sesuai CD interaktif dan menemukan produk pangan baru dengan rancangan formulasi yang sudah didiskusikan dalam bentuk lembar kerja. Pada langkah ketujuh mahasiswa mempersiapkan praktik, kemudian melakukan uji coba/eksperimen produk baru. Kegagalan produk pangan sesuai kriteria uji kualitas, jika belum memperoleh nilai maksimal dilakukan evaluasi formulasi produk pangan baru tersebut, dengan demikian produk pangan harus diuji coba ulang lagi sampai memperoleh nilai maksimal (sesuai kriteria uji kualitas). Kegagalan dalam pembuatan produk menyebabkan pengulangan praktik 2 kali terjadi pada 5 orang mahasiswa dan pengulangan praktik 3 kali terjadi pada 3 orang mahasiswa di kelompok pertama. Sedangkan pada kelompok kedua kegagalan dialami oleh 8 orang mahasiswa dengan pengulangan praktik 2 kali, 5 orang mahasiswa dengan pengulangan praktik 3 kali dan 2 orang mahasiswa dengan pengulangan praktik sampai 4 kali. Pengulangan praktik dilakukan karena produk yang dibuat belum mencapai kriteria uji kualitas yang diharapkan. Penilaian uji kualitas pada setiap produk pangan baru dilakukan secara organoleptik oleh 3 orang panelis yang terdiri dari pembuat produk dan dosen pengampu mata kuliah tersebut.

Berarti produk yang sudah memenuhi kriteria uji kualitas merupakan produk yang baik. Produk pangan baru ini dibuat dalam bentuk CD Interaktif Pangan Kreatif dan Inovatif dengan formulasi produk terdiri dari persiapan alat, persiapan bahan, proses pembuatan, dan produk pangan baru yang sudah dikemas. Setiap produk pangan dilengkapi dengan ciri khas produk pangan yang merupakan keunggulan produk, kelemahan produk, dan hasil uji kualitas.

\section{Menemukan produk pangan baru yang kreatif dan inovatif}

Hasil penelitian berdasarkan Lembar Kerja penelitian pangan ini berupa hasil penilaian lembar kerja I, II dan III, untuk memperoleh data pemanfaatan CD Interaktif Pangan melalui kemampuan mahasiswa untuk menemukan produk pangan baru yang kreatif dan inovatif, yaitu:

1. Kemampuan

mahasiswa menemukan ide/masalah untuk menemukan produk pangan baru pada kelompok pertama lebih tinggi dari kelompok kedua berdasarkan lembar kerja I. Produk pangan baru berdasarkan perubahan formulasi yaitu bahan utama, bahan pelengkap, prosedur kerja dan penyajian produk (kemasan)

2. Kemampuan mahasiswa membuat rancangan eksperimen pada kelompok kedua sedikit lebih tinggi dari kelompok pertama berdasarkan lembar kerja II Hal ini disebabkan pada kelompok kedua lebih intensif melakukan bimbingan pada dosen pengampu mata kuliah dan juga pengulangan uji coba lebih sering dilakukan oleh kelompok kedua.

3. Kemampuan mahasiswa membuat laporan eksperimen, dokumentasi dan presentasi hasil kegiatan pada kelompok pertama (nilai rata-rata 31,2 ) dan kelompok kedua (nilai rata-rata 30,2) hampir sama berdasarkan lembar kerja III.

Jurnal Pendidikan Indonesia | 492 
Pada tahapan pelaksanaan uji kualitas ini, setiap produk pangan memiliki kekhasan yang berbeda satu dengan lainnya, sehingga setiap mahasiswa membuat instrumen untuk uji organoleptik yang berbeda untuk setiap produk pangan dengan bimbingan dari dosen pengampu mata kuliah tersebut. Oleh sebab itu terdapat perbedaan kriteria uji kualitas, kemudian dianalisis secara kualitatif pada setiap produk pangan. Uji kualitas dilakukan berdasarkan instrumen (alat ukur) sebagai tolok ukur produk yang dibuat oleh mahasiswa dengan bimbingan peneliti. Secara umum kriteria produk pangan yang dilakukan dengan penilaian organoleptik terdiri dari kriteria rasa, warna, tekstur, bentuk produk, kerataan permukaan, besarnya poripori, ketinggian produk, kemasan produk dan sebagainya. Tetapi tidak semua kriteria produk pangan tersebut dapat diukur dengan uji kualitas, beberapa dapat diukur dengan uji selera. Pengukuran uji selera berdasarkan kesenangan konsumen, budaya yang berlaku atau kebiasaan yang ada di masyarakat. Kriteria rasa lebih pada selera konsumen, kriteria kemasan produk juga sangat tergantung selera konsumen dan kebiasaan yang ada di masyarakat.

Pembuatan media pembelajaran pangan berbasis CD (Compact Disk) interaktif ini meliputi 6 tahapan, yaitu: konsep, disain, pengumpulan material, pembuatan (assemby), testing, dan distribusi. a) konsep dan disain CD Interaktif direncanakan sebelum eksperimen produk pangan dilaksanakan. b) pengumpulan material pada langkah awal dilakukan melalui studi pustaka dari dokumen hasil penelitian, buku-buku pangan dan melalui penelusuran di internet. Langkah selanjutnya pengumpulan material melalui dokumentasi eksperimen produk pangan yang meliputi persiapan alat, persiapan bahan, proses pengolahan produk dan catatan hasil analisis produk pangan. c) proses pembuatan CD interaktif dilakukan secara bertahap, sesuai penyelesaian eksperimen. Sedangkan analisis produk pangan merupakan materi terakhir yang dibuat untuk CD Interaktif. d) testing dan distribusi dilakukan untuk memperoleh CD interaktif yang optimal dengan beberapa revisi.

Materi produk pangan baru yang inovatif dan kreatif, diperoleh sebanyak 16 produk pangan baru berdasarkan hasil eksperimen mahasiswa. Produk pangan baru ini memiliki formulasi yang kreatif dan inovatif, karena selain memenuhi kriteria uji kualitas produk, juga memiliki dokumentasi dan laporan yang maksimal. Sedangkan produk lainnya memiliki dokumentasi dan laporan yang tidak lengkap, meskipun produk pangan baru tersebut memenuhi kriteria uji kualitas. Adapun tampilan 16 produk pangan baru tersebut dapat dilihat pada gambar-gambar, sebagai berikut: 


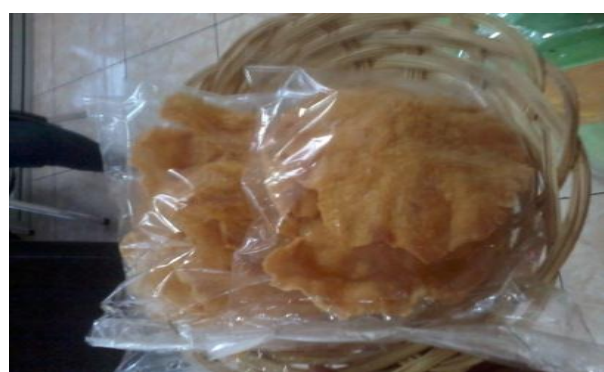

Gambar 1. Opak Wortel

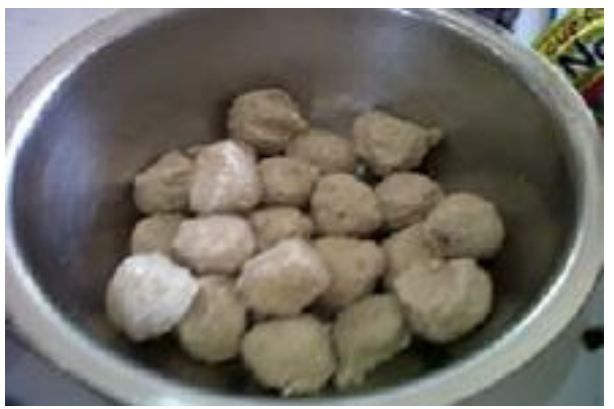

Gambar 3. Bakso Timbul

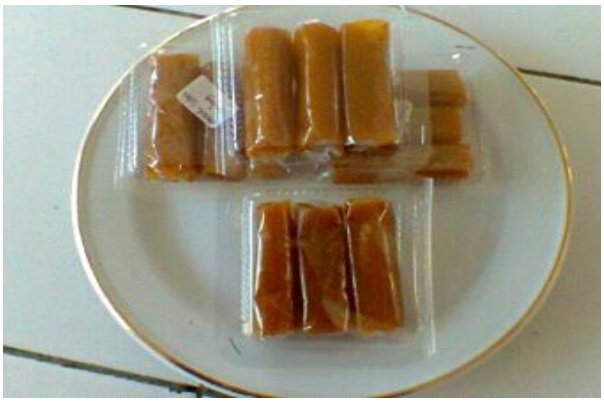

Gambar 5. Dodol Labu Kuning

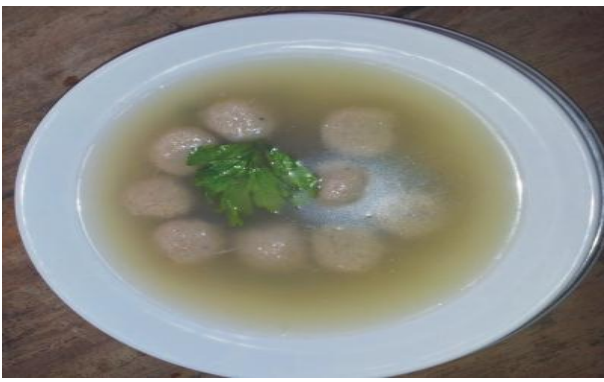

Gambar 7. Bakso Ampas Tahu
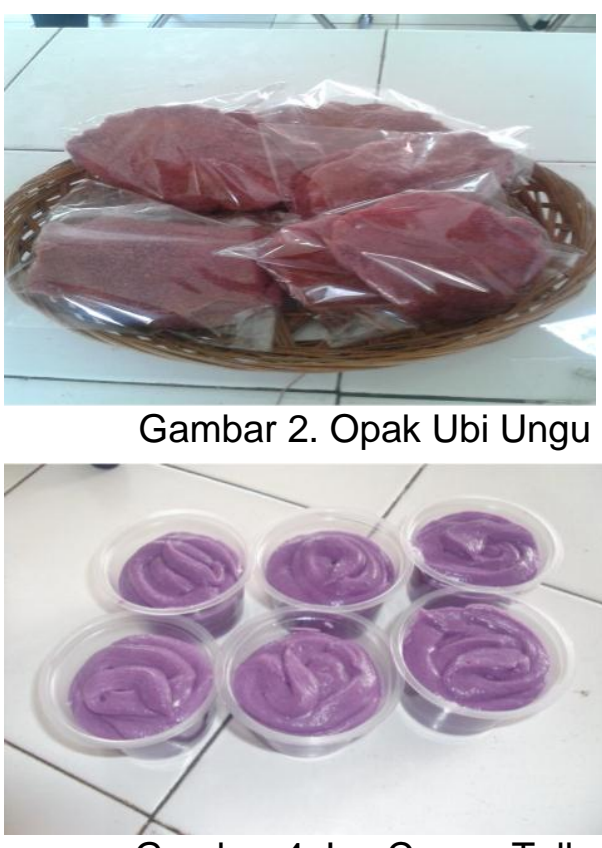

Gambar 4. Ice Cream Tello

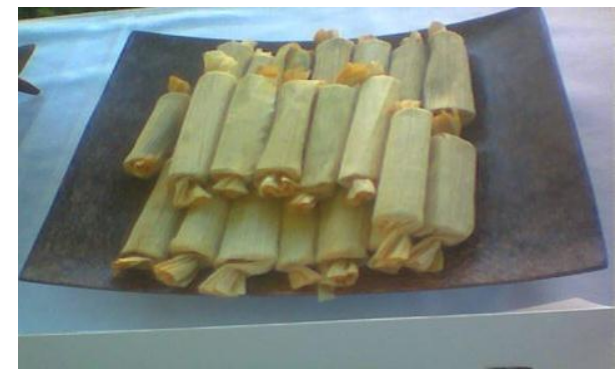

Gambar 6. Dodol Wortel

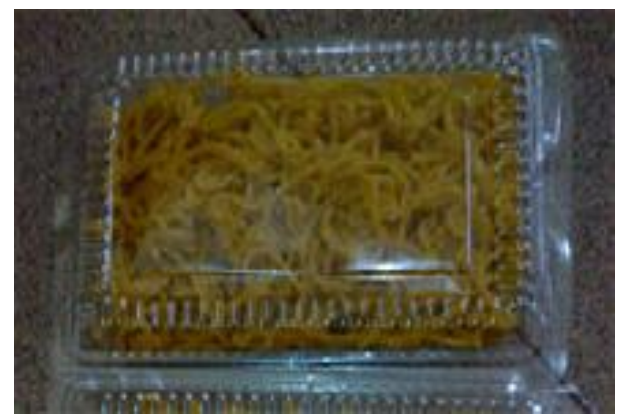

Gambar 8. Mi Wortel 


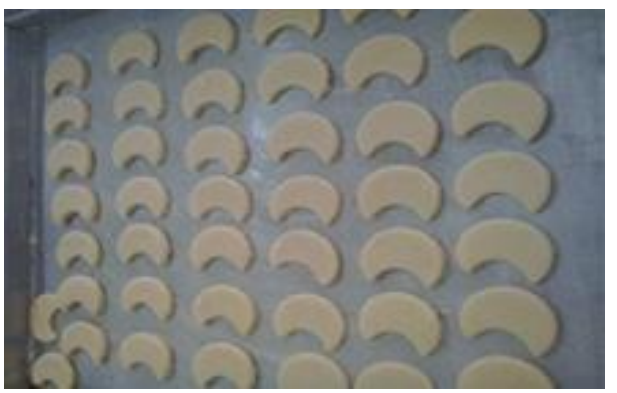

Gambar 9. Cookies Ubi

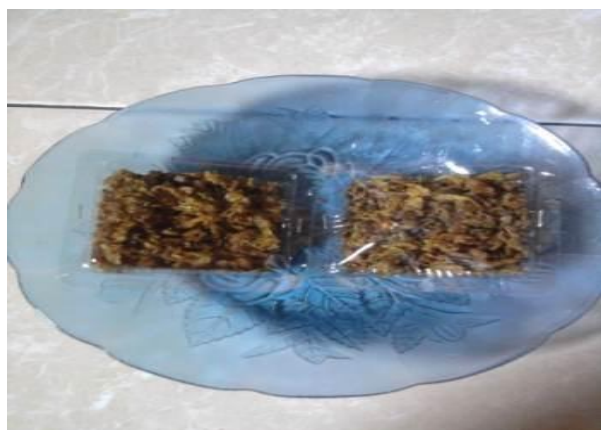

Gambar 5.11. Abon Timbul

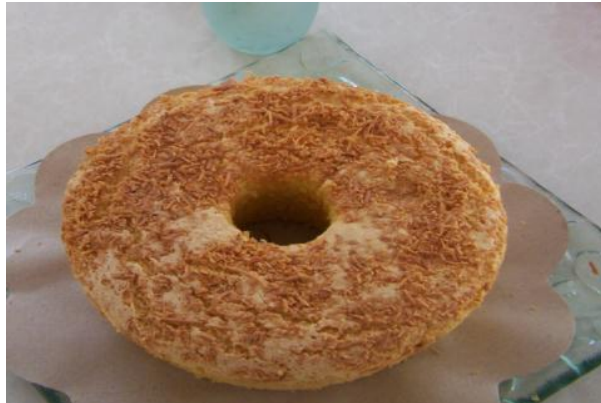

Gambar 5.13. Chiffon Ubi Jalar

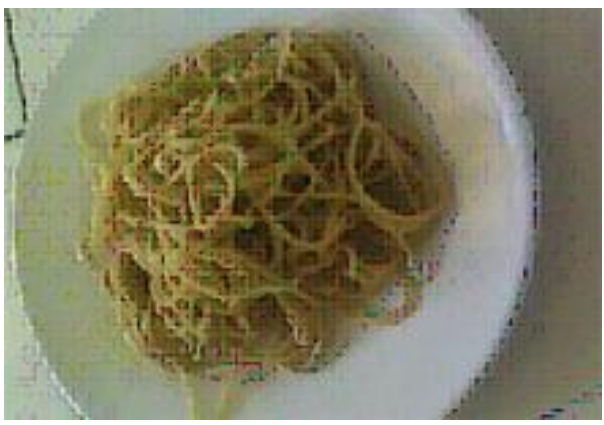

Gambar 5.15. Mi Sukun

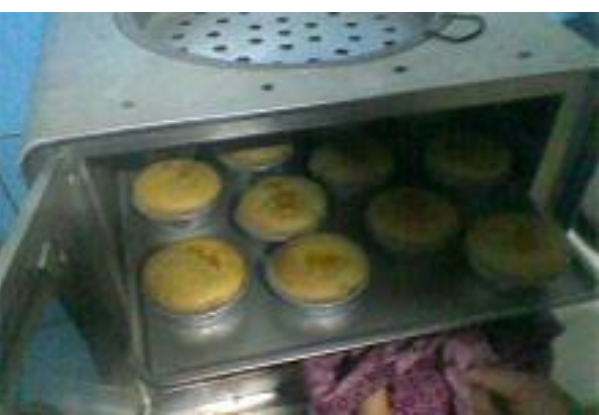

Gambar 10. Cake Tamarillo

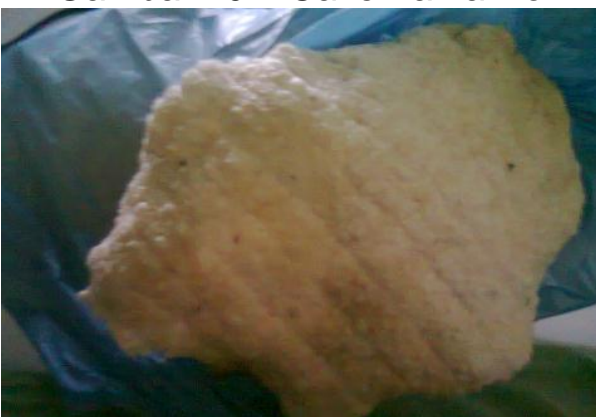

Gambar 5.12. Opak Ampas tahu

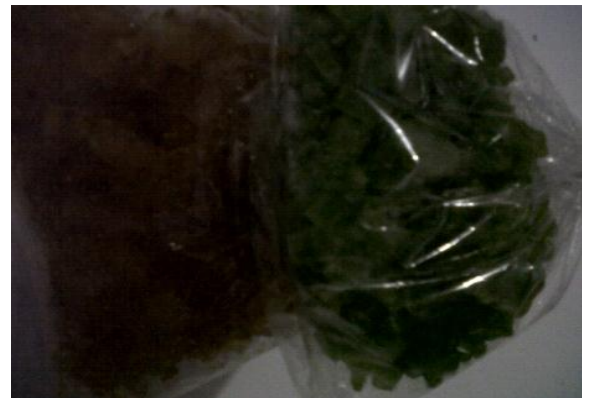

Gambar 5.14. Sukade

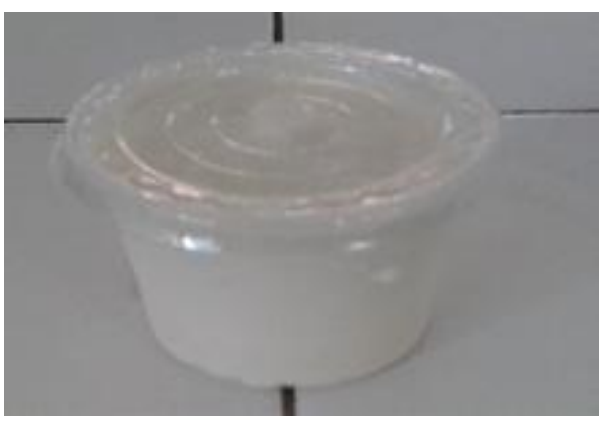

Gambar 5.16. Yoghurt Nabati

Jurnal Pendidikan Indonesia | 495 
Penelitian ini memberikan perlakuan yang berbeda pada dua kelompok belajar mata kuliah pengawetan makanan. Perlakuan yang membedakan pada pemberian media belajar CD Interaktif pada kelompok pertama, sedangkan kelompok II tidak diberikan CD Interaktif. Langkah kerja ilmiah peningkatan mutu pangan ini meliputi 8 kegiatan pada mata kuliah Pengawetan Makanan. Penemuan Resep (formula) produk pangan baru yang inovatif dan kreatif diperoleh melalui eksperimen yang berulang-ulang sampai ditemukan produk yang sesuai dengan kriteria produk. Produk pangan baru yang diperoleh dari penelitian ini terdiri dari 16 resep.

Penggunaan

media pembelajaran pangan berbasis hasilhasil penelitian boga (CD Interaktif Pangan) pada mata kuliah Pengawetan Makanan dapat meningkatkan pengetahuan, keterampilan dan aktivitas mahasiswa. Hal ini disebabkan mahasiswa lebih mudah memahami materi atau mencapai sasaran pembelajaran dalam praktik produk pangan secara perorangan dengan melihat media pembelajaran dalam bentuk CD interaktif pangan.

Pemanfaatan

media pembelajaran pangan (CD Interaktif Pangan) dapat meningkatkan kemampuan mahasiswa untuk menemukan produk pangan baru yang kreatif dan inovatif. Hal ini disebabkan timbulnya ide kreatif pada mahasiswa dengan melihat produk-produk pangan baru yang merupakan hasil-hasil penelitian pangan (skripsi dan penelitian boga di Jurusan PKK, Undiksha)

Selain itu dampak ikutan dalam penelitian ini mahasiswa memiliki pengalaman dalam berpikir rasional (mulai menyusun rancangan sampai laporan) dan melakukan pengkomunikasian melalui presentasi. Tanggapan mahasiswa terhadap program pembelajaran ini secara umum adalah positif, maksudnya adalah sebagian besar setuju dengan program pembelajaran ini. Hal ini disebabkan mahasiswa lebih mudah memahami materi atau mencapai sasaran pembelajaran dengan melihat contoh dalam bentuk media pembelajaran pangan.

Penelitian ini mengembangkan media pembelajaran pangan berbasis multimedia dalam bentuk CD interaktif pangan yang kreatif dan inovatif dalam pembelajaran mata kuliah Pengawetan Makanan. Hal ini dilakukan dengan didasarkan atas hasil kajian evaluatif dan rekomendasi hasil-hasil penelitian boga yang ada. Kemudian dilanjutkan tahun kedua pada tahapan melakukan uji coba untuk menyempurnakan media pembelajaran ini.

\section{PENUTUP}

Penelitian ini memberikan perlakuan yang berbeda pada dua kelompok belajar mata kuliah pengawetan makanan. Perlakuan yang membedakan pada pemberian media belajar CD Interaktif pada kelompok pertama, sedangkan kelompok II tidak diberikan CD Interaktif, sedangkan perlakuan lainnya sama. Langkah kerja ilmiah peningkatan mutu pangan ini meliputi 8 kegiatan pada mata kuliah Pengawetan Makanan untuk 12 kali pertemuan, yaitu (1) pengungkapan pengetahuan awal tentang upaya peningkatan mutu pangan dan keterampilan kerja ilmiah awal; (2) 
pembekalan peningkatan mutu pangan; (3) memiliki pengalaman langsung (praktik-Lembar Observasi 1) tentang peningkatan mutu pangan; menemukan ide inovatif produk pangan bermutu; (5) membuat rancangan produk pangan baru; (6) pelaksanaan praktik oleh mahasiswa; (praktikLembar Observasi 2); (7) pembuatan media tentang produk pangan baru; (8) pengkomunikasian produk pangan baru melalui presentasi hasil di kelas.

Penemuan Resep (formula) produk pangan baru yang inovatif dan kreatif diperoleh melalui eksperimen yang berulang-ulang sampai ditemukan produk yang sesuai dengan kriteria produk. Pembuatan media pembelajaran pangan sudah mendokumentasikan produk pangan yang meliputi a) prakata (home); b) Produk pangan baru yang terdiri dari keperluan alat, bahan, proses dan uji kualitas produk yang dilengkapi dengan gambar-gambar. Produk pangan baru yang diperoleh dari penelitian ini terdiri dari 16 resep sebagai berikut Opak Wortel, Opak Ubi Ungu, Bakso Timbul, Ice Cream Tello, Dodol labu kuning, Dodol wortel, Bakso Ampas Tahu, Mie Wortel, Cookies Ubi, Cake Tamarillo, Abon Timbul, Opak Ampas tahu, Chiffon Ubi Ungu, Sukade, Mi Sukun dan Yoghurt Nabati.

\section{Penggunaan}

media pembelajaran pangan berbasis hasilhasil penelitian boga (CD Interaktif Pangan) pada mata kuliah Pengawetan Makanan dapat meningkatkan pengetahuan, keterampilan dan aktivitas mahasiswa. Hal ini disebabkan mahasiswa lebih mudah memahami materi atau mencapai sasaran pembelajaran dalam praktik produk pangan secara perorangan dengan melihat media pembelajaran dalam bentuk CD interaktif pangan.

$$
\text { Pemanfaatan }
$$

media

pembelajaran pangan (CD Interaktif Pangan) dapat meningkatkan kemampuan mahasiswa untuk menemukan produk pangan baru yang kreatif dan inovatif. Hal ini disebabkan timbulnya ide kreatif pada mahasiswa dengan melihat produk-produk pangan baru yang merupakan hasil-hasil penelitian pangan (skripsi dan penelitian boga di Jurusan PKK, Undiksha)

Selain itu dampak ikutan dalam penelitian ini mahasiswa memiliki pengalaman dalam berpikir rasional (mulai menyusun rancangan sampai laporan) dan melakukan pengkomunikasian melalui presentasi. Tanggapan mahasiswa terhadap program pembelajaran ini secara umum adalah positif, maksudnya adalah sebagian besar setuju dengan program pembelajaran ini. Hal ini disebabkan mahasiswa lebih mudah memahami materi atau mencapai sasaran pembelajaran dengan melihat contoh dalam bentuk media pembelajaran pangan.

Saran dalam penelitian ini sebagai berikut:

1. Untuk mencapai optimalisasi pembelajaran tentang peningkatan mutu pangan, dapat memberikan pengalaman belajar melalui media pembelajaran CD interaktif, karena lebih mudah dipahami. Meskipun memerlukan bimbingan dan pengarahan yang intensif agar tidak terjadi kegagalan produk pangan.

2. Agar aktivitas kegiatan pembelajaran tinggi, siswa dimotivasi untuk menemukan sendiri produk pangan 
baru yang kreatif dan inovatif sesuai kondisi lingkungan.

3. Pada pengampu mata kuliah (pendidik) disarankan untuk menanamkan cara berpikir rasional secara maksimal, karena hal ini akan mempersiapkan mahasiswa dalam menyikapi tuntutan hidup di masyarakat.

4. Usaha untuk meningkatkan mutu pangan sangatlah luas meskipun dalam perspektif pembelajaran, untuk itu diperlukan penelitian lanjutan mengenai peningkatan mutu pangan yang meliputi bidang pertanian, serta teknologi pangan.

\section{DAFTAR PUSTAKA}

Astawan, Made. 1991. Teknologi Pengolahan Pangan Nabati. Jakarta. Penerbit: Akademika Pressindo.

Dewi, Luisa Rishe Purnama. 2007. Gatra: Media Pembelajaran dan Pengembangan Bahan Ajar.USD: Yogyakarta.

Fidiatno, Ides. 2007. Pembelajaran Berbasis Multimedia

Penerapan Perangkat $\mathrm{T}$ I $\mathrm{K}$ Dalam Pengembangan Kegiatan Belajar Mengajar, http://media.diknas.go.id/media/d ocument/5335.pdf, diakses 10 Februari 2011
Hermawan Thaheer. 2005. Sistem Manajemen HACCP (Hazard Analysis Critical Control Points). Jakarta. Penerbit: Bumi Aksara.

Istanto, Freddy H. 2001. Potensi dan Kaidah Perancangan Situs Web Sebagai Media Komunikasi visual. Nirmana, Volume 3. No.1

Nazrina Zuryani, N. dkk (2008) Studi Pelacakan Keterserapan Lulusan Jurusan Pendidikan Kesejahteraan Keluarga Fakultas Teknik dan Kejuruan Universitas Pendidikan Ganesha, Laporan Penelitian yang dibiayai oleh dana DIPA.

Nursanti Riandini. 2008. Seri Kimia dalam Kehidupan Sehari-hari: Bahan Kimia dalam Makanan dan Minuman. Bandung. Penerbit: Shakti Adiluhung.

Risa Panti Ariani., 2005. Optimalisasi Pembelajaran Kecakapan Hidup tentang Peningkatan Produksi Pangan di SMPN 2 Singaraja, Laporan Penelitian. Dirjen Pendidikan Tinggi, Dep. Pendidikan Nasional.

Sudrajat, Akhmad. 2008. Media Pembelajaran.http://akhmadsudr ajat.wordpress.com/2008/01/12/ media-pembelajaran/, diakses tanggal 6 Februari 2010. 